\title{
Reproductive ecology, spawning potential, and breeding season of blue swimming crab (Portunidae: Portunus pelagicus) in Java Sea, Indonesia
}

\author{
TRI ERNAWATI ${ }^{1}$, BAMBANG SUMIONO ${ }^{2}$, HAWIS MADDUPPA ${ }^{3,4,5, \boldsymbol{v}}$ \\ ${ }^{1}$ Research Institute for Marine Fisheries, Ministry of Marine Affairs and Fisheries, Jakarta Utara 14440, Indonesia \\ ${ }^{2}$ Center for Fisheries Research and Development, Ministry of Marine Affairs and Fisheries, Jakarta, 14440 Indonesia \\ ${ }^{3}$ Department of Marine Science and Technology, Faculty of Fisheries and Marine Science, Institut Pertanian Bogor. J1. Raya Darmaga, Kampus IPB \\ Darmaga, Bogor 16680, West Java, Indonesia. ”email: hawis@apps.ipb.ac.id \\ ${ }^{4}$ Indonesian Blue Swimming Crab Association. J1. KIG Raya Selatan Kav C-5, Gresik 61121, East Java, Indonesia \\ ${ }^{5}$ Center for Coastal and Marine Resource Studies, Institut Pertanian Bogor. Jl. Raya Pajajaran No. 1, Kampus IPB Baranangsiang, Bogor 16217, West \\ Java, Indonesia
}

Manuscript received: 20 September 2017. Revision accepted: 30 October 2017.

\begin{abstract}
Ernawati T, Sumiono B, Madduppa H. 2017. Reproductive ecology, spawning potential, and breeding season of blue swimming crab (Portunidae: Portunus pelagicus) in Java Sea, Indonesia. Biodiversitas 18: 1705-1713. The blue swimming crab (Portunidae: Portunus pelagicus) is one of the most economically important fisheries species in Indonesia. Little is known about their reproductive ecology and key biological characteristics. This study aimed to investigate population biology and reproductive ecology (Carapace's width to weight relationship, growth, natural mortality, size at first maturity and at first captured, Spawning Potential Ratio (SPR), and breeding season) of P. pelagicus at six important landing sites around the Java Sea (Jakarta, Cirebon, Demak, Rembang, Sumenep, and Sampit) from January 2014 to January 2015. Monthly data were collected by fishers at each landing sites, with a total of 14,408 individuals being measured. The study found that males were heavier than females and the smallest mean of individuals' height belonged to Jakarta compared to other locations. The growth parameters varied at the different locations. Crabs could grow up to 100 $\mathrm{mm}$ in 10 months with the maximum age being less than three years. The growth rate $(\mathrm{K})$ of more than 1 indicated a fast-growing crustacean with a short lifespan. The lowest carapace width at first capture $\left(\mathrm{L}_{\mathrm{c}}\right)$ for the BSC was obtained from crabs caught using a bottom gillnet landed in Jakarta, followed by dredged crabs in Cirebon. The mean carapace width at first maturity $\left(\mathrm{L}_{\mathrm{m}}\right)$ in the Java Sea was $10.6 \mathrm{~cm}$, with the lowest $\mathrm{L}_{\mathrm{m}}$ of female crabs being landed in Cirebon and the highest in Sampit. The Spawning Potential Ratio (SPR) ranged from $11 \%$ to $24 \%$ and the selectivity curve for the BSC fishery at each landing sites is positioned well to the right of the generic maturity curve, except in Demak, suggests that the operation enables almost all crabs to mature and spawn before entering the fishery. The collapsible trap was the most selective gear, with an average catch of $112 \mathrm{~mm}$ across at all landing sites, and the least selective was in trawls. Therefore consideration needs to be given to the different gear types used to catch crabs to leave smaller crabs in the water longer to grow to maturity. Considering its fast growth and peak season (February-April and August-October), a short-period is recommended at some sites that have been over-exploited to rebuild a broodstock to support the long-term sustainability of this species.
\end{abstract}

Keywords: fishing gear, minimum landing size, seafood, sustainable fisheries, small-scale fisheries

\section{INTRODUCTION}

The blue swimming crab (BSC; Portunus pelagicus, locally called as Rajungan) is one of the most economically important fishery species in Indonesia, after tuna and shrimp (Fauzi, 2013). BSC is found across the IndoPacific, the Indian Ocean to the west and eastern Pacific Ocean $(\mathrm{Ng}, 1998)$, and in Indonesia, it is widely distributed including the east coast of Sumatra, northern coast of Java, south and east Kalimantan, Southeastern of Sulawesi and south-west of Papua (Sumiono, 1997). The annual BSC catch in Indonesia has fluctuated between 1970-2014. Catch levels increased between 1970 and 2004, but then, they declined in 2004-2005, before they increased again in the following years. In 2008 , the estimated crab production reached 34,000 tons, which was approximately $20 \%$ of global production, second only to production in China (FAO 2011 in Chu et al. 2012). Crabs contributed 44\% of the total national production (42,000 tons), and 18,500 tons of them came from the Java Sea (MMAF 2012).

Determining life histories of harvested species are important to ensure the sustainability of the species in the wild. Sustainable management requires information on the size and age at maturity, size distribution patterns, agespecific reproductive investment and spawning time (Stearns 1989, Sukumaran and Neelakantan 1996, 1997, Hamid et al. 2016, La Sara et al. 2016)). It is also important to understand the characteristics of the fishery including information on harvest strategy (Campbell and Eagles 1983, Addison and Bennett 1992), and harvesting rules (Gerhart and Bert 2008). Earlier studies have shown intraspecific, and interspecific variation in the reproductive biology characteristics of $P$. pelagicus explained by, areaspecific and regional differences; e.g. in Malaysia (Ikhwanuddin et al. 2009, Ikhwanuddin et al. 2012), in India waters (Sahoo et al. 2011), and in Philippines (Ingles and Bkaum 1989). Brachyuran crabs are categorized as 
iteroparous species, which have considerable variation in reproduction patterns (Hines 1982, Hines 1989). The reproductive periodicity of $P$. pelagicus follows a continuous pattern in tropical and subtropical regions (Batoy et al. 1987, Sumpton et al. 1994). The reproduction periodicity may be subdivided into three categories (Pinheiro and Fransozo 2002): (i) seasonal reproduction, either the presence of the females with mature gonad or the presence of ovigerous females begin during certain months or seasons; (ii) continuous, when ovigerous females occur across all months of the year; and (iii) seasonal-continuous, the presence of ovigerous females in all months of the year, but with distinguishable peak in abundance of gravid females in some months or seasons.

Since 2015, the National Commission for Stock Assesment under Ministry of Marine Affairs and Fisheries has included The Spawning Potential Ratio (SPR) as one of a method to measure the stock and health of the fishery. The SPR is the ratio of an average crab's lifetime reproductive potential under fishing, and the reproductive potential it would have in the absence of fishing. It measures the proportional reduction in reproductive potential caused by fishing. It is a function of fishing pressure $(\mathrm{F})$, and the productivity of a particular species (M) and so is effectively proportional to F/M (Hordyk et al. $2015 \mathrm{~b})$. The SPR is an index of the relative rate of reproduction in an exploited stock. The basic concept of SPR is a proportion of the un-fished reproductive potential left by fishing pressure. Un-fished stock and individuals in an un-fished stock have an SPR of $100 \%\left(\mathrm{SPR}_{100 \%}\right)$, and fishing mortality decreases $\mathrm{SPR}_{100 \%}$ from the unfished level to $\mathrm{SPR}_{\mathrm{X} \%}$ (Prince et al. 2015).

Fishing activities in BSC fisheries carried out in a relatively short time on each trip by small-scale fishers, and they have one-day fishing as seen in Southeast Sulawesi (Madduppa et al. 2016). The common fishing gears used to catch BSC in Indonesia are bottom trawl (locally: "arad"), bottom gill net (locally: "kejer") and collapsible traps (locally: "Bubu"), which have listed as national fishing gears (DJCF, 2012). According to Nomura (1974) and Sumiono and Widodo (2006), the effectiveness of different fishing gears are different based on the gear design, materials and the method in which the gear is used.

Despite the importance of BSC in Indonesia, there is a poor understanding of its population dynamics, especially in the Java Sea, which is one of the most important fishing grounds in Indonesia and has the most fishermen. The aim of this study was to investigate the population biology (including the carapace width to weight relationship, size at first maturity and when first captured, and breeding season) and the spawning potential ratio of $P$. pelagicus in Java Sea at six selected important landing sites (Jakarta, Cirebon, Demak, Rembang, Sumenep and Sampit). We discuss the results of our study in the context of BSC fisheries management and conservation.

\section{MATERIALS AND METHODS}

\section{Data collection}

The study was conducted at six selected sites around the Java Sea (i.e., Jakarta, Cirebon, Demak, Rembang, Sumenep, and Sampit) from January 2014 to January 2015. Regular monthly sampling was undertaken at each site (Figure 1). A total of 14,408 individual crabs were collected across the landing sites during the study period (Table 1). Biological variables measured included: carapace width $(\mathrm{mm})$, individual weight $(\mathrm{g})$ and sex. The gonadal maturity stages were identified based on Sumpton et al. (1994). Catch, and effort-data were collected from fishermen or middlemen, including catch composition, catch per trip (kg), a number of trips and fishing gear used.

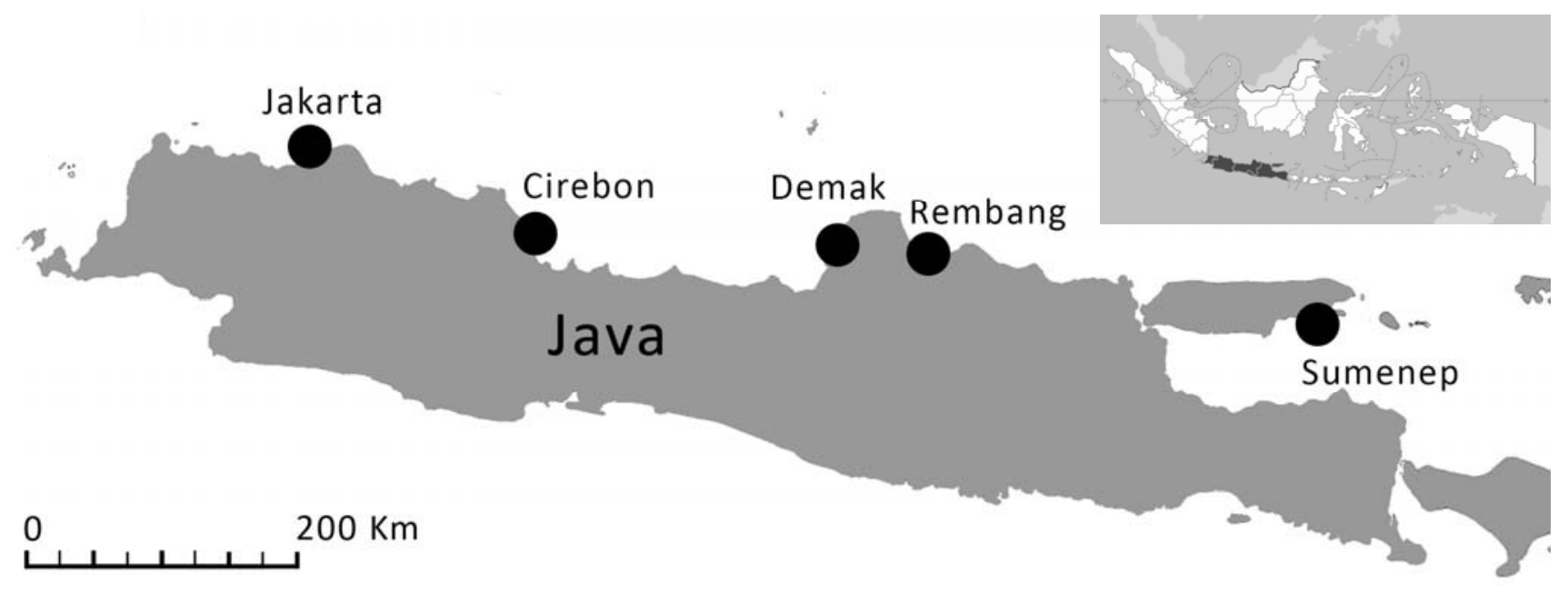

Figure 1. The location of BSC sampling sites in the Java Sea 
Table 1. Number of Portunus pelagicus samples based on sex (male and female) at each landing site during the sampling period.

\begin{tabular}{llll}
\hline Site & Period & Male & Female \\
\hline Cirebon & July-Dec 2014 & 1,333 & 718 \\
Demak & Jan-Dec 2014 & 1,536 & 1,433 \\
Rembang & Jan-Dec 2014 & 1,679 & 1,995 \\
Sumenep & Jan-Dec 2014 & 2,360 & 2,156 \\
Sampit & March-May 2014 & 302 & 253 \\
Jakarta & Dec 2014-Jan 2015 & 315 & 311 \\
Total & & 7,525 & 6,866 \\
\hline
\end{tabular}

\section{Data analysis}

Carapace width to weight relationship

The carapace width to weight relationship was fitted using power regression for male and female BSC separately as follows: $W=a^{*} C W^{b}$, where $\mathrm{CW}$ is the carapace width, $a$ is the initial growth coefficient, and $b$ is slope or growth coefficient (Ricker 1973). The relationship between carapace width to individual weight of males and females was tested using a t-test, to test whether isometric or allometric.

\section{Growth}

The growth parameters of BSC were determined by fitting the von Bertalanffy growth function $C W_{t}=C W_{\infty} *\left(1-e^{-{ }^{k}(t-}\right.$

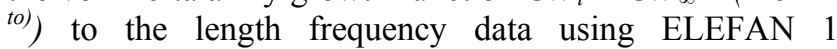
incorporated in FiSAT II (Gayanilo et al., 2005), where $\mathrm{CW}_{\mathrm{t}}$ is the carapace width at the time $\mathrm{t} ; \mathrm{CW}_{\infty}$ is the asymptotic carapace width; $\mathrm{k}$ is the growth coefficient; $\mathrm{t}_{\mathrm{o}}$ is the theoretical carapace width at age 0 . Maximum age $\left(t_{\max }\right)$ was calculated using empirical equation from Pauly (1980), $\mathrm{t}_{\max } \approx 3 / \mathrm{k}$, where $\mathrm{k}$ is the growth coefficient.

\section{Natural Mortality}

The natural mortality was estimated by the formula of Pauly (1980). Pauly mentioned there was water temperature influenced to natural mortality rate, as follows: $\log M=-0,0066-0,279 \log C W_{\infty}+0,6543 \log k+0,4634$ $\log T$, where $\mathrm{M}$ is natural mortality, $\mathrm{CW}_{\infty}$ is the asymptotic carapace width; $\mathrm{k}$ is the growth coefficient, $\mathrm{T}$ is mean of waters temperature.

\section{Size at first maturity and at first captured}

Size at first maturity $\left(\mathrm{CW}_{\mathrm{m}}\right)$ was estimated by fitting a logistic curve to the relationship between the proportion of mature females in each size class, using the following formula $\mathrm{P}=1 /\left(1+\exp \left(-\mathrm{r}\left(\mathrm{CW}-\mathrm{CW}_{\mathrm{m}}\right)\right)\right.$, where $\mathrm{P}$ is the proportion of mature females BSC and $\mathrm{r}$ is a constant (King 1995). Determination of female crab gonads based on Sumpton et al. (1994), as follows: stage 1, no macroscopic mark of gonad; stage 2 immature of gonad, white or transparent, diameter of oocytes up to $0.14 \mathrm{~mm}$; stage 3, maturing of gonad, light orange, not spreading into hepatic region, oocyte diameter $0.15-0.21 \mathrm{~mm}$; stage 4 , mature of gonad, bright orange, spreading into hepatic region, diameter of oocyte $0.22-0.40 \mathrm{~mm}$.

Calculating the average size of crabs when first captured $\left(\mathrm{CW}_{50}\right)$ or $\mathrm{CWc}$ in the same gear as the trap trawl selectivity approach is to use the escape gap logistic function. The formula used is as follows: $\mathrm{r}(\mathrm{CW})=\exp$ $(\mathrm{a}+\mathrm{b} C W) / 1+\exp (\mathrm{a}+\mathrm{b} C W)$, where $\mathrm{r}(C W)$ is the opportunity for crabs of certain size to be retained, $C W$ is carapace width of crabs that are captured, $a$ and $b$ are selectivity curve parameters $(a<0$ and $b>0)$, so the carapace width where $50 \%$ retained, $\mathrm{CW}_{50}$ or $\mathrm{CWc}$ will be: $\mathrm{CW}_{50}=-\mathrm{a} / \mathrm{b}$.

\section{Spawning Potential Ratio (SPR)}

An assessment of SPR was performed using the assessment software developed by Dr. Adrian Hordyk, Murdoch University (Hordyk et al. 2015), with the webbased interface. The SPR Reference Points used are as follows: (i) SPR 20\%: Biological Limit Reference Point below which reproductive potential should be maintained before recruitment is impaired (Bunnel and Miller 2005b) and (ii) SPR 40\%as the Biological Target Reference Point for ensuring sustainability (Hordyk et al. 2015b). Calculating SPR was needed some parameters life history by the ratios $\mathrm{M} / \mathrm{k}, \mathrm{F} / \mathrm{M}$, and $\mathrm{CW}_{\mathrm{m}} / \mathrm{CW}_{\infty}$ (Hordyk et al. 2015a).

\section{Breeding season}

The abundance and size of ovigerous crabs in Cirebon, Demak, Rembang, and Sumenep was recorded each month. Reproductive patterns for a breeding season were determined by a monthly distribution of mature female gonad and the proportion of ovigerous to the adult females (Rasheed and Mustaquim 2010, de Lestang et al. 2003a, $2003 \mathrm{~b}, 2003 \mathrm{c})$. Analysis of reproductive pattern was also completed by gonad condition of an ovigerous female. We propose that the spawning female population by estimating the relative percentage of adult females and ovigerous in each 5-mm CW size class, as well as their ratio as performed by Rasheed and Mustaquim (2010) and Zairion et al. (2015). Determination of ovigerous stages following Sumpton et al. (1994), as follows: stage 1, non-ovigerous; stage 2, ovigerous with egg mass paly to dark yellow, no eyespots outward in eggs; stage 3, ovigerous with yellowgrey of egg mass, present of eyespot; stage 4, ovigerous with grey egg mass, eyespots and chromatophores observable; stage 5 , spent.

\section{RESULTS AND DISCUSSION}

\section{Carapace width to weight relationship and width composition, growth, and size at first maturity and at first captured}

The males were heavier significantly than that of females as shown by a bigger $b$ exponent for males (Table 2 ). The values for the exponent (b) in the present study $(b<3$ or $b>3$ ) indicated allometric growth. We found that the mean carapace width for both male and female in Jakarta was the smallest (males: $95.3 \pm 10.7 \mathrm{~cm}$, and females: $94.5 \pm 11.4$ ), and the highest at Sampit for both males $(134.6 \pm 14.7)$ and females $(132.0 \pm 14.3)$, compared with all other locations (Table 3). Our study found that males were heavier than females and growth were allometric. The mean width for male and female BSC in Jakarta was the smallest, while the largest carapace widths of both males and females were observed at Sampit. 
Table 2. Carapace width to weight relationship for BSC at different landing sites (significance level, $p>0.05=$ n.s., $p<0.05=*$ )

\begin{tabular}{|c|c|c|c|c|c|c|c|}
\hline \multirow{2}{*}{ Sex } & \multirow{2}{*}{ Variable } & \multicolumn{6}{|c|}{ Carapace width-weight relationship $\left(\mathrm{W}=\mathrm{aL}^{\mathrm{b}}\right)$} \\
\hline & & Jakarta & Cirebon & Demak & Rembang & Sumenep & Sampit \\
\hline \multirow{3}{*}{ Male } & $\mathrm{a}$ & $7.00 \mathrm{E}-05$ & $4.00 \mathrm{E}-05$ & $8.00 \mathrm{E}-06$ & $2.00 \mathrm{E}-05$ & $3.10 \mathrm{E}-03$ & $2.00 \mathrm{E}-05$ \\
\hline & $\mathrm{b}$ & $2.995^{\text {n.s. }}$ & $3.106^{*}$ & $3.449 *$ & $3.280 *$ & $2.220^{*}$ & $3.310^{*}$ \\
\hline & $\mathrm{R}^{2}$ & 0.922 & 0.865 & 0.963 & 0.932 & 0.8303 & 0.8830 \\
\hline \multirow{3}{*}{ Female } & $\mathrm{a}$ & $1.20 \mathrm{E}-04$ & $6.00 \mathrm{E}-05$ & $1.80 \mathrm{E}-05$ & $1.00 \mathrm{E}-05$ & $3.23 \mathrm{E}-02$ & $5.00 \mathrm{E}-05$ \\
\hline & $\mathrm{b}$ & $2.880^{\text {n.s }}$ & $3.0234^{\mathrm{n} . \mathrm{s}}$ & $3.2695^{*}$ & $3.394 *$ & $1.7118 *$ & $3.0722 *$ \\
\hline & $\mathrm{R}^{2}$ & 0.8714 & 0.8668 & 0.935 & 0.947 & 0.8311 & 0.81 \\
\hline \multirow{3}{*}{ All } & $\mathrm{a}$ & $1.00 \mathrm{E}-04$ & $4.00 \mathrm{E}-05$ & $1.00 \mathrm{E}-05$ & $2.00 \mathrm{E}-05$ & $1.07 \mathrm{E}-02$ & $2.00 \mathrm{E}-05$ \\
\hline & $\mathrm{b}$ & $2.9304^{\mathrm{n} . \mathrm{s}}$ & $3.102 *$ & $3.347 *$ & $3.201 *$ & $1.953 *$ & $3.221 *$ \\
\hline & $\mathrm{R}^{2}$ & 0.8955 & 0.8678 & 0.9443 & 0.928 & 0.8092 & 0.8512 \\
\hline
\end{tabular}

Table 3. Carapace width size of male and female BSC at each landing sites during study period

\begin{tabular}{|c|c|c|c|c|c|c|}
\hline \multirow[t]{2}{*}{ Site } & \multicolumn{3}{|c|}{ Male Size (mm) } & \multicolumn{3}{|c|}{ Female Size (mm) } \\
\hline & $\min$ & $\max$ & mean \pm SD & $\min$ & $\max$ & mean \pm SD \\
\hline Jakarta & 73.4 & 152.0 & $95.3 \pm 10.7$ & 69.1 & 122 & $94.5 \pm 11.4$ \\
\hline Cirebon & 71.1 & 151.3 & $111.6 \pm 11.6$ & 60.0 & 152.6 & $108.1 \pm 14.7$ \\
\hline Demak & 58.8 & 168.4 & $110.4 \pm 18.1$ & 40.4 & 166.1 & $112.6 \pm 18.2$ \\
\hline Rembang & 70.4 & 159.2 & $115.3 \pm 15.5$ & 75.4 & 165.6 & $116.4 \pm 15.8$ \\
\hline Sumenep & 75.6 & 148.0 & $116.0 \pm 15.6$ & 77.2 & 143.8 & $114.9 \pm 17.0$ \\
\hline Sampit & 87.0 & 165.0 & $134.6 \pm 14.7$ & 90.0 & 183 & $132.0 \pm 14.3$ \\
\hline
\end{tabular}

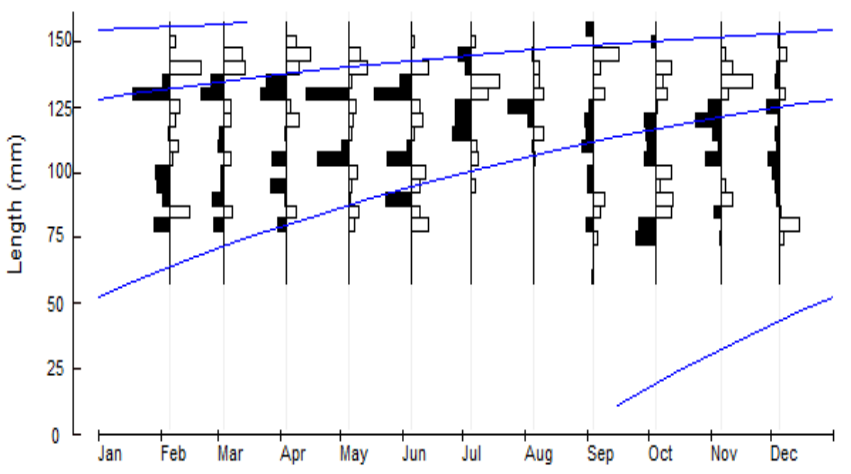

A

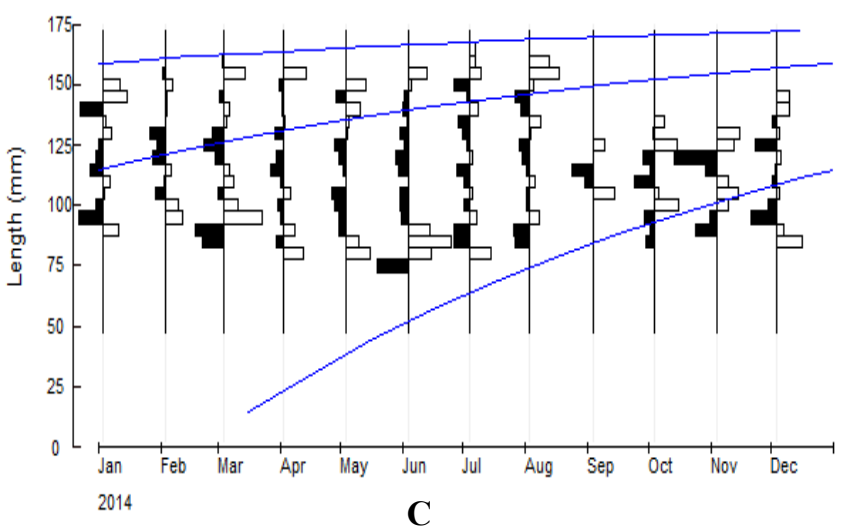

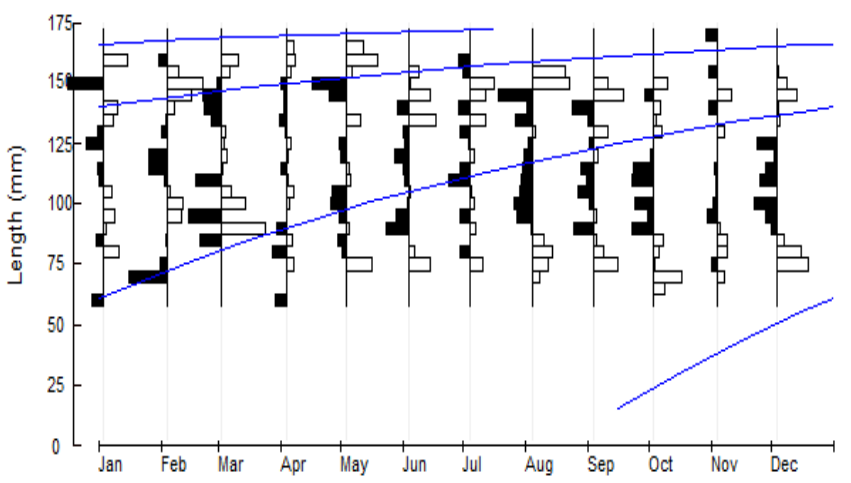

B

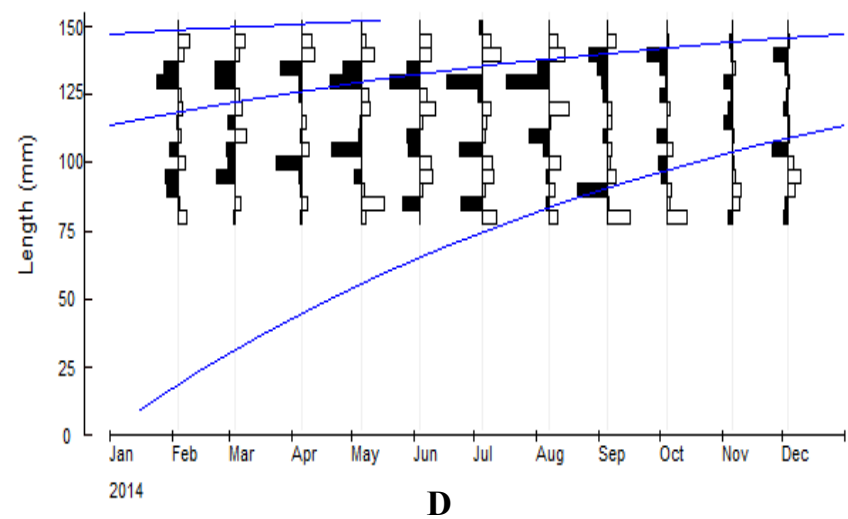

Figures 2. Growth of blue swimming crabs based on monthly carapace width distribution at four landing sites (A. Cirebon, B. Demak, C. Rembang, D. Sumenep) in 2014 
Table 4. The growth parameters of combine male and female of BSC: $\mathrm{CW}_{\infty}(\mathrm{mm})=$ Carapace width at infinity, $\mathrm{K}$ (per year) $=$ growth rate, $\mathrm{t}_{\mathrm{o}}=$ age, $\mathrm{t}_{\max }$ (year) $=$ maximum age of $\mathrm{BSC}$ at each landing site

\begin{tabular}{|c|c|c|c|c|}
\hline \multirow[t]{2}{*}{ Site } & \multicolumn{4}{|c|}{ Growth parameters } \\
\hline & $\mathbf{L}_{\infty}(\mathbf{m m})$ & $\begin{array}{c}\text { K (per } \\
\text { year) }\end{array}$ & $\mathbf{t}_{\mathbf{o}}$ & $t_{\max }($ year $)$ \\
\hline Cirebon & 168.60 & 1.05 & -0.1040 & 2.86 \\
\hline Demak & 179.35 & 1.11 & -0.1083 & 2.70 \\
\hline Rembang & 178.80 & 1.18 & -0.1155 & 2.54 \\
\hline Sumenep & 161.40 & 1.21 & -0.1219 & 2.48 \\
\hline
\end{tabular}

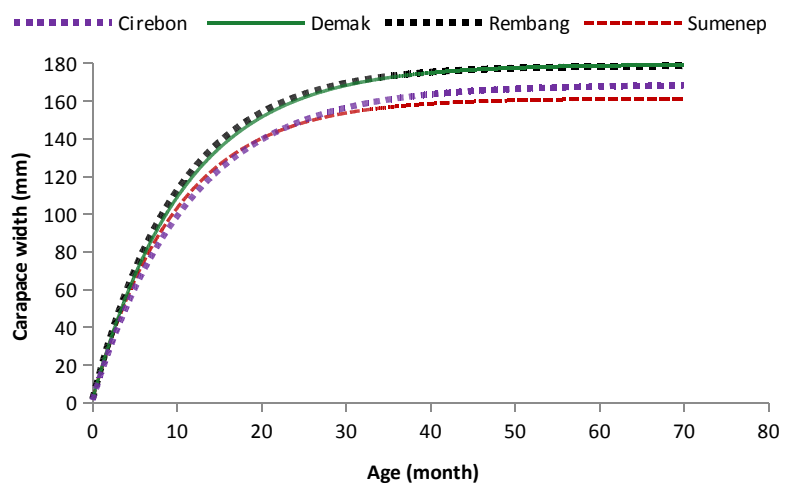

Figure 3. The growth curves for blue swimming crabs at different landing sites

Table 5. The mean carapace width $(\mathrm{mm})$ at first maturity $(\mathrm{CWm})$ and mean carapace width at first capture $\left(\mathrm{CW}_{\mathrm{c}}\right)$ of $\mathrm{BSC}$ with different fishing gear used at each landing site

\begin{tabular}{llllll}
\hline \multicolumn{1}{c}{ Site } & \multicolumn{1}{c}{$\begin{array}{c}\mathbf{C W m} / \\
(\mathbf{m m})\end{array}$} & $\begin{array}{c}\text { CWe/ (mm) } \\
\text { Collapsible } \\
\text { trap }\end{array}$ & $\begin{array}{c}\text { Mini } \\
\text { Gill Net } \\
\text { bottom } \\
\text { trawl }\end{array}$ & $\begin{array}{c}\text { Dredge } \\
\text { Net }\end{array}$ \\
\hline Jakarta & $\mathrm{n} / \mathrm{a}$ & 100.21 & 93.64 & - & - \\
Cirebon & 99.23 & 109.01 & 107.22 & 108.52 & 99.38 \\
Demak & 104.89 & 123.32 & 101.34 & 105.43 & - \\
Rembang & 101.06 & 115.72 & 108.84 & - & - \\
Sumenep & 101.86 & 114.13 & - & - & - \\
Sampit & 123.89 & - & 130.96 & - & - \\
\hline
\end{tabular}

The growth parameters varied between the sampling locations. The growth of BSC based on monthly carapace width distribution at four landing sites is shown in Figure 2. The von Bertalanffy growth equation was used to determine the maximum age of BSC in each location. The infinite carapace width of combine male and female BSC at the four landing sites was ranged from 161.4 to 179.3 ; the maximum age was less than three year with fast growth $(\mathrm{K}$ $>1$ ) 1. (Table 4, Figure 3). The condition of gonad has been used to estimate of body size at sexual maturity for male and female (Castiglioni and Negreiros-Fransozo 2006) or allometric changes in growth of the body parts is related to functional maturity (Rasheed and Mustaquim 2010) or both (de Lestang et al. 2003a, 2003b).
The infinite carapace width at four landing sites was ranged from 161.4 to 179.3 , and they can reach size up to $100 \mathrm{~mm}$ in 10 months, with maximum age was less than 3 years and growth rate $(\mathrm{K})$ has indicated a fast growth as shown by $\mathrm{K}$ value more than 1 , showing that BSC in study area is a fast-growing crustacean with a short lifespan. This dynamic condition of growth parameter seems influenced by the differences of environment oceanography and exploitation rate. According to Beverton (1963) in Pauly (1980) that maximum carapace width $\left(\mathrm{CW}_{\max }\right)$ is achieved approximately $95 \%$ of asymptotic carapace width $\left(\mathrm{CW}_{\infty}\right)$.

The mean carapace width at first maturity $\left(\mathrm{CW}_{\mathrm{m}}\right)$ in the Java sea at the sampled landing sites was $10.6 \mathrm{~cm}$ (Table 5 ), with the lowest $\mathrm{CW}_{\mathrm{m}}$ of female crabs being landed in Cirebon and the highest in Sampit. The carapace width at first capture $\left(\mathrm{CW}_{\mathrm{c}}\right)$ of BSC was varied at six landing sites. The lowest $\mathrm{CW}_{\mathrm{c}}$ was obtained from bottom gillnet in Jakarta and followed by dredge net in Cirebon (Table 5). The highest $\mathrm{CW}_{\mathrm{c}}$ was observed from Collapsible trap and gill net from Demak and Sampit, respectively. The mean carapace width at first maturity $\left(\mathrm{CW}_{\mathrm{m}}\right)$ in the Java Sea at our study sites was $10.6 \pm 1.01 \mathrm{~cm}$ carapace width. Synchronous physiological and functional maturity was found in females when studied by both approaches, but some asynchrony was found for some studies of males. Therefore, physiological maturity is often used to determine the size at sexual maturity of females portunid crabs, since there is an actual capacity to release gametes, which corresponds to functional maturity (Castiglioni and Negreiros-Fransozo 2006). Also, morphometric maturity does not always indicate functional maturity ( $\mathrm{Oh}$ and Hartnoll 1999) or may not coincide with physiological sexual maturity (Choy 1988). Previous studies on the northern coast of Java (Hermanto 2004; Sunarto 2012) and in East Lampung (Zairion et al. 2015) have found that the mean size at which $50 \%$ of females sexually mature (Lm50; judged by gonad condition) to be 105, 101 and 103 $\mathrm{mm} \mathrm{CW}$, respectively. Biometric data from ovigerous females Portunus pelagicus are not different by the embryonic development that characterized by the eggs color (Hamid et al. 2015).

This study found that mean $\mathrm{CW}_{\mathrm{c}}$ was bigger than $\mathrm{CW}_{\mathrm{m}}$ indicating that the caught crabs had already spawned. The lowest $\mathrm{CW}_{\mathrm{c}}$ for $\mathrm{BSC}$ was obtained from bottom gillnet caught crabs landed in Jakarta, followed by crabs caught in dredge nets in Cirebon. The lowest $\mathrm{CW}_{\mathrm{c}}$ for BSC was obtained from crabs caught by bottom gillnet landed in Jakarta, followed by dredge net caught crabs in Cirebon. This can be explained by the fishing area for bottom gillnet (Jakarta), and dredge net (Cirebon) in both locations are around near-shore areas such as estuaries. However, the mean $\mathrm{L}_{\mathrm{c}}$ was bigger than $\mathrm{L}_{\mathrm{m}}$ indicating that crabs caught in this study had spawned at least once. This situation must be maintained to ensure the long-term sustainability of the BSC stocks, especially in the Java Sea. Another factor that might influence the maturity size of BSC is fishing intensity because it may reduce the density of the species (de Lastang et al. 2003a, Dixon and Hooper 2011). Fishing area or sampling site (i.e., estuarine versus offshore) may also influence the mean size at maturity of female $P$. 
pelagicus due to the emigration of mature females from estuaries to offshore habitats (de Lastang et al. 2003b, 2003c; Johnson et al. 2010).

\section{Breeding season}

The percentage distribution of ovigerous females crab in Cirebon, Demak, Rembang, and Sumenep was variable, and ovigerous females were recorded throughout the year at all sites (Figure 4). The peak spawning season occurred in different months at four sampling locations: Cirebon in March and August, Demak in March and October, Rembang in February and October, and Sumenep in March, May, and September. In general, the peak-spawning season in those locations had two peaks, between February-April and August-October.

Our analysis of $P$. pelagicus reproductive patterns was supported by supplementary evidence of the occurrence of ovigerous females and their ovarian conditions. The peak of ovigerous in each month identified the peak-spawning season. In this study, the ovigerous females were observed through the year, with two peaks, between February-April and August-October. The reproduction periodicity in the study sites was categorized as seasonal-continuous, due to the presence of an ovigerous female in all months of the year, but with a distinguishable peak in some months or seasons (Pinheiro and Fransozo 2002). In South Australia waters that the peak period for ovary maturation and spawning starts in October with a peak of ovigerous females occurring in November-December (Clarke and Ryan, 2004). In tropical regions, Portunus pelagicus breeds throughout the year (Batoy et al., 1987). The peak of spawning or breeding season varied between locations and might relate to different environmental condition prevailing in that period, such as changes in temperature, salinity, rainfall, food availability, and predators (Pinhero et al. 2012).

\section{Spawning Potential Ratio (SPR)}

The life history parameters at each site were calculated and used to estimate the status of the BSC population at each landing site using the Length Based Spawning Potential Ratio (LB SPR) approach (Table 6). The estimated spawning potential ratio (SPR) for BSC was $11 \%, 15 \%$, and $15 \%$ at Cirebon, Demak, and Rembang, respectively (Table 7). An SPR below $20 \%$ is below the Biological Limit Reference Point where reproductive potential and recruitment is impaired. While the SPR in Madura was $24 \%$, it was below $30 \%$ meaning it was still below the Biological Target Reference Point target to ensure sustainability (Table 8 ). The length on the selectivity of the catch in the Java Sea was $123.5 \mathrm{~mm}( \pm 1.4 \mathrm{~mm})$ and $158.7 \mathrm{~mm}( \pm 2.04 \mathrm{~mm})$ between $50 \%$ and $95 \%$ respectively. The output from the maturity and selectivity curves calculated by the LB SPR is shown in Figure 5.

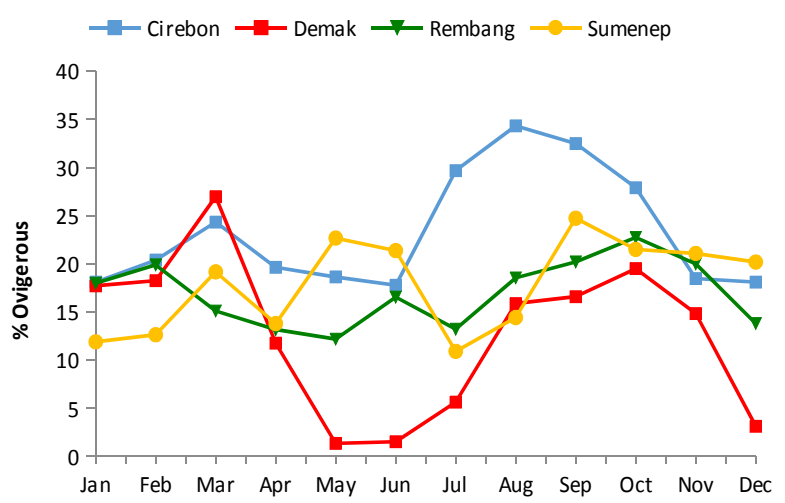

Figure 4. The monthly percentage of ovigerous females blue swimming crabs during 2014 at four landing sites

Table 6. The life history parameters used to estimate the stock status of the blue swimming crabs fishery in the study sites, using the length based spawning potential ratio approach

\begin{tabular}{llllll}
\hline The life history paramenters & Cirebon & Demak & Rembang & Sumenep & Java Sea \\
\hline Mortality/Growth Ratio $(\mathrm{M} / \mathrm{K})$ & 1.392 & 1.393 & 1.394 & 1.394 & 1.393 \\
Size on Maturity $(50 \%)\left(\mathrm{L}_{50}\right)$ & 99.23 & 104.89 & 101.06 & 101.86 & 101.57 \\
Size on Maturity $(95 \%)\left(\mathrm{L}_{95}\right)$ & 110 & 121 & 118 & 144 & 125 \\
$\mathrm{CWm} / \mathrm{CW} \infty$ Ratio $(\mathrm{CWm} / \mathrm{CW} \infty)$ & 0.588 & 0.585 & 0.565 & 0.628 & 0.534 \\
Length Infinity $\left(\mathrm{L}_{\infty}\right)$ & 168.6 & 179.35 & 178.8 & 161.4 & 190 \\
B $($ egg production $\alpha$ length) & 3 & 3 & 3 & 3 & 3 \\
\hline
\end{tabular}

Table 7. Parameter Estimates (SD) from the Length Based Spawning Potential Ratio assessment of the blue swimming crabs fishery in the Java Sea for F/M (Fishing Mortality to Natural Mortality Ratio), SPR (Spawning Potential Ratio), $\mathrm{S}_{\mathrm{L} 50}$ (Length on 50\% Selectivity) and $\mathrm{S}_{\mathrm{L} 95}$ (Length on $95 \%$ Selectivity).

\begin{tabular}{lllll}
\hline \multicolumn{1}{c}{ Site } & \multicolumn{1}{c}{ F/M } & SPR & \multicolumn{1}{c}{$\mathbf{S}_{\text {L50 }}$} & $\mathbf{S}_{\text {L95 }}$ \\
\hline Cirebon & $5.13(0.765)$ & $0.11(0.006)$ & $109.7(2.805)$ & $136.5(4.314)$ \\
Demak & $2.16(0.135)$ & $0.15(0.008)$ & $97.4(1.264)$ & $118.9(2.419)$ \\
Rembang & $3.92(0.33)$ & $0.15(0.004)$ & $114.2(1.74)$ & $141.3(2.833)$ \\
Sumenep & $10.97(0.56)$ & $0.24(0.004)$ & $144(0)$ & $182.7(0.739)$ \\
Java Sea & $5.24(0.341)$ & $0.15(0.002)$ & $123.5(1.445)$ & $158.7(2.049)$ \\
\hline
\end{tabular}



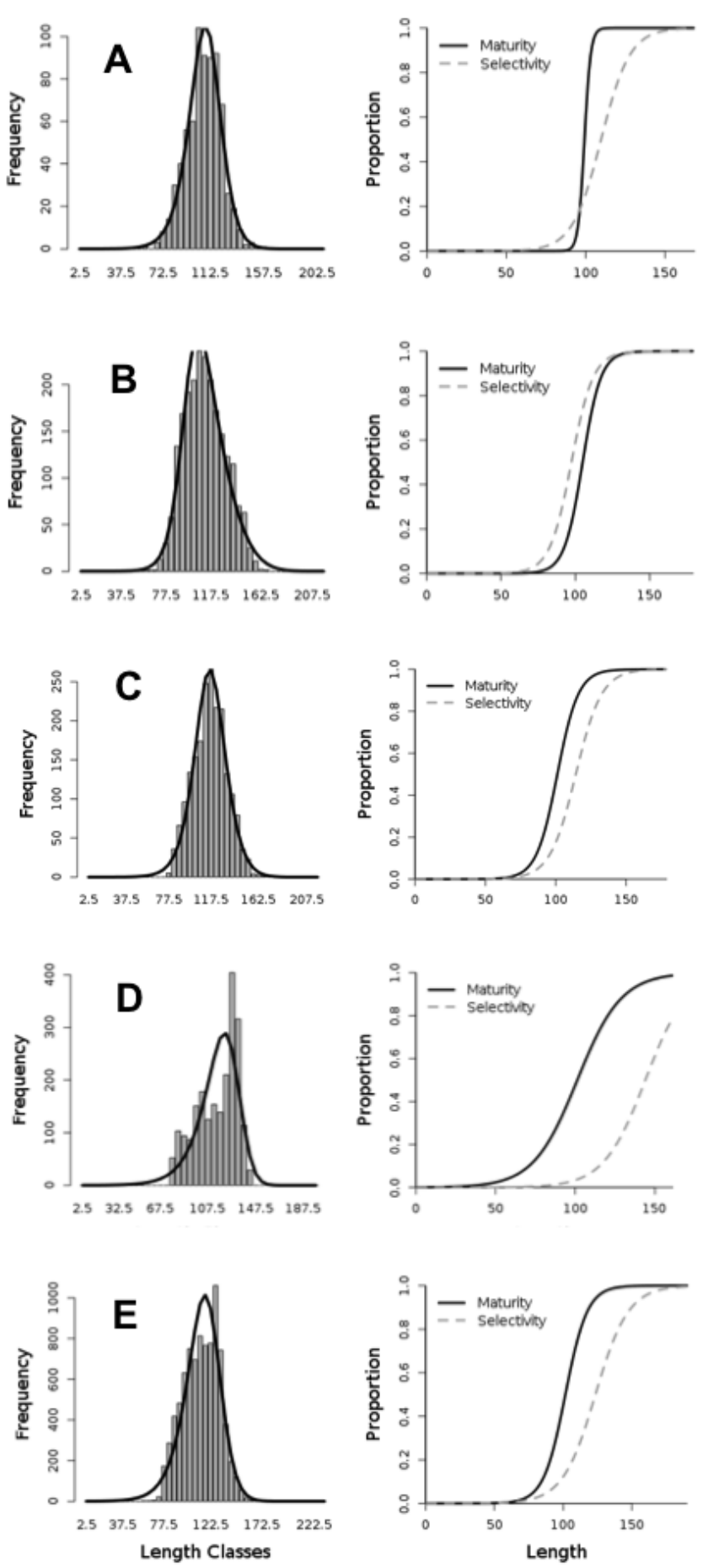

Figure 5. Frequency distribution of carapace length classes and proportion of different lengths at each site showing selectivity and maturity of captured crab at each site (A: Cirebon, B: Demak, C: Rembang, D: Madura, and E: Java Sea-Total)

The ratio of fishing mortality to natural mortality $(\mathrm{F} / \mathrm{M})$ was $5.24( \pm 0.34)$, with the highest value in Sumenep $(10.97 \pm 0.56)$ and the lowest in Demak (2.16 \pm 0.13$)$. The selectivity curves are shown in Figure 5.

Despite the mean $\mathrm{Lm}$ being $10.6 \mathrm{~cm}$, the SPR ranged from 11 to $15 \%$ in Cirebon, Demak, Rembang, while in
Madura it was 24\%. To assist the recovery of the BSC stock in the Java Sea or to increase the SPR to the $20 \%$ level (the biological sustainability reference point) a minimum $12 \mathrm{~cm}$ carapace width is needed. Revisiting an earlier analysis (see Clark 1991), and after considering recruitment variability, Clark (1993) recommended SPR $40 \%$ as maximum sustainable yield (MSY) proxies. More recently Clark (2002) expanded his analyses to consider lower values of slope (steepness) at the origin of the stock-recruitment-relationship, as might be expected for long-lived rockfish, but he still recommended a single level of SPR that would be sustainable for most fish without causing too much reduction in yield and to maintain more resilient stocks. He concluded that SPR $>40 \%$ should meet current management needs, but noted that for very low productivity species, the appropriate fishing level could be $\mathrm{F} 60 \%$ or even $\mathrm{F} 70 \%$ (Clark 2002). However, the BSC is fast growing and has high productivity; the SPR $40 \%$ could be used as target reference point. These analyses could become the basis for the SPR Reference Points widely recognized under Indonesian fisheries laws.

\section{Implications for fishery management}

Based on our findings we suggest the following. (i) A closed season for the fishery to conserve a brood stock. Plotting the number ovigerous or egg-berried females for each month would identify when this closed season should be implemented. The peak occurrence of ovigerous females in the Java Sea happens in September, October, and November. This assumes that after a couple of days the ovigerous females will hatch their eggs. We proposed that the closed season should be between March-May and August-September. (ii) We recommend a Minimum Landing Size for the P. pelagicus fishery in the Java Sea, which should be greater than Lm50 and we proposed 106 $\mathrm{mm} \mathrm{CW}$. This was the size of the mean ratio of ovigerous females to adult females, meaning that $21.38 \%$ of the spawning females in the population would have become part of the breeding population. This would be an appropriate pre-cautionary approach for maintaining a spawning and breeding female population and therefore stock productivity. This could be monitored through integrated traceability tools (see Madduppa et al. 2016). (iii) Concerning fishing gear selectiveness, the collapsible trap was the most selective gear, with an average size of BSC up to $112 \mathrm{~mm}$ at all landing sites, and the least selective was trawling. These results indicate that the ban on trawling as announced by the Ministry of Marine and Fishery decree No. 2/2015 could support the sustainability of BSC. The different gear types might need different forms of management to achieve the outcome of leaving smaller crabs in the water longer to grow. Boutson et al. (2009) mention that escapes gaps could be fitted to traps and that minimum size limits could apply to the catch of traps, dip-nets, and trammel nets, while mini-trawling could be kept to deeper water, where the larger crabs occur. Overall, optimal harvest control rules for any fishery resources bases on fishery management purposes, and keep maintaining the law enforcement of the MLS and fishing gear regulation. 
In conclusion, the study observed that $\mathrm{BSC}$ is a fast growing (100 mm in months) and a short lifespan (less than three years). The most selective fishing was observed at the collapsible trap. The Spawning Potential Ratio (SPR) and the selectivity curve for the BSC fishery at each landing sites are positioned well to the right of the generic maturity curve, except in Demak, suggests that the operation enables almost all crabs to mature and spawn before entering the fishery. Therefore consideration needs to be given to the different gear types used to catch crabs to leave smaller crabs in the water longer to grow to maturity. Considering its fast growth and peaks season (February-April and August-October), a closed-period is recommended at some sites that have been over-exploited to rebuild a broodstock to support the long-term sustainability of this species.

\section{ACKNOWLEDGEMENTS}

The study was funded by Indonesian blue swimming crab Association (APRI) under MoU No. 4.1/Balitbang KP.1/KKP/PKS/X/2013. We also acknowledge the in-kind contribution of Research Institute for Marine Fisheries (BRPL), Ministry of Marine Affairs and Fisheries during onboard observation, supporting technical staff and laboratory analyses. We also thank Cirebon and Demak Fisheries Offices for their administrative support and permission to make field observations. The significant contribution of fishers experience is also acknowledged. Special thanks also to Prof. Dr. H.E. Irianto for his support on implementing public-private partnerships on strengthening the research base assessment to initiate crabs fisheries management plans in the Java Sea, Indonesia.

\section{REFERENCES}

Addison JT, Bennett DB. 1992. Assessment of minimum landing sizes of the edible crab, Cancer pagurus L. on the east coast of England. Fish Res 13 (1): 67-88.

Batoy CB, Sarmago JF, Pilapil BC. 1987. Breeding season, sexual maturity and fecundity of the blue crab, Portunus pelagicus (L.) in selected coastal waters in Leyte and vicinity, Philippines. Ann Trop Res 9: 157-177.

Brooks EN, Powers JE, Cortes E. 2010. Analytical reference points for age-structured models: application to data-poor fisheries. ICES J Mar Sci 67 (1): 165-175.

Bunnell DB, Miller TJ. 2005. An individual-based modeling approach to spawning potential per-recruit models: an application to blue crab (Callinectes sapidus) in Chesapeake Bay. Can J Fish Aqua Sci 62: 2560-2572.

Campbell A, Eagles MD. 1983. Size at maturity and fecundity of rock crabs, Cancer irroratus, from the Bay of Fundy and south western Nova Scotia. Fish Bull 81 (2): 357-362.

Castiglioni DS, Negreiros-Fransozo ML. 2006; Physiologic sexua maturity of the fiddler crab Uca rapax (Smith, 1870) (Crustacea, Ocypodidae) from two mangroves in Ubatuba, Brazil. Braz Arch Biol Technol 49 (2): 239-248.

Choy SC. 1988 Reproductive biology of Liocarcinus puber and L. holsatus (Decapoda, Brachyura, Portunidae) from the Gower Peninsula, South Wales. Mar Ecol 9 (3): 227-241.

Chu J, Anderson JL, Anderson CM. 2012. Evaluation of New Fishery Performance Indicators (FPIs) : A case study of the Blue Swimming Crab Fisheries in Indonesia and Philippines. Agric. and Rural Dev. Discussion Paper 52. The World Bank. Washington, DC.
Clarke K, Ryan S. 2004. Ecological assessment of the Queensland blue swimmer crab pot fishery Departement of Primary Industries and Fisheries. 100p.Crawford, J. 2013. US market demand for sustainability and fishing gear requirements for blue swimmer crab FIPs. The National Workshop on Fishing and Management of Blue Swimming Crab in North coast of Java. Semarang, October $22^{\text {th }}$, 2013

de Lestang S, Hall NG, Potter IC. 2003a. Changes in density, age composition, and growth rate of Portunus pelagicus in a large embayment in which fishing pressures and environmental conditions have been altered. J Crustacean Biol 23 (4): 908-919.

de Lestang S, Hall NG, Potter IC. 2003b. Reproductive biology of the blue swimmer crab (Portunus pelagicus, Decapoda: Portunidae) in five bodies of water on the west coast of Australia. Fish Bull 101 (4): 745-757.

de Lestang S, Hall NG, Potter IC. 2003c. Influence of a deep artificial entrance channel on the biological characteristics of the blue swimmer crab Portunus pelagicus in a large microtidal estuary. J Exp Mar Biol Ecol 295: 41-61.

Dixon CD, Hooper GE. 2011. Blue crab (Portunus pelagicus) 2009/2010, Stock assessment report to PIRSA Fisheries. South Australian Research and Development Institute (Aquatic science). Adelaide (AU): SARDI Publication; SARDI Report Series. (531). Report No.: F2007/000729-7.

Fauzi S. 2013. Policy in the development on marketing of Indonesian fishery. The National Workshop on Fishing and Management of Blue Swimming Crab in North coast of Java. Semarang, October 22th, 2013.

Gayanilo Jr FC, Sparre P, Pauly D. 2005. FAO-ICLARM Stock Assessment Tools II (FISAT II). User's guide. FAO Computerized Information Series (Fisheries) No. 8. Revised Version. FAO. Rome, Italy.

Gerhart SD, Bert TM. 2008 Life-history aspects of stone crabs (Genus Menippe): Size at maturity, growth, and age. J Crustacean Biol 28 (2): 252-261.

Hamid A, Wardiatno Y, Batu DTFL and Riani E (2015) Changes in Proximate and Fatty Acids of the Eggs during Embryo Development in the Blue Swimming Crab, Portunus pelagicus (Linnaeus 1758) at Lasongko Bay, Southeast Sulawesi, Indonesia. Indian J Sci Technol 8 (6): 501-509.

Hines AH. 1982 Allometric constraints and variables of reproductive effort in brachyuran crabs. Mar Biol 69 (3): 309-320.

Hines AH. 1989. Geographic variation in size at maturity in brachyuran crabs. Bull Mar Sci 45 (2): 356-368.

Hordyk A, Loneragan N, Prince JD. 2015a. An evaluation of an iterative harvest strategy for data-poor fisheries using the length-based spawning potential ratio assessment methodology. Fish Res 171: 2032.

Hordyk A, Ono K, Sainsbury K, Loneragan N, Prince JD. 2015b. Some explorations of the life history ratios to describe length composition, spawning-per-recruit, and the spawning potential ratio. ICES J Mar Sci 72 (1): 204-216

Ikhwanuddin M, Azra MN, Siti-Aimuni H, Abol-Munafi AB. 2012. Fecundity, embryonic and ovarian development of blue swimming crab, Portunus pelagicus (Linnaeus 1758) in coastal waters of Johor, Malaysia. Pakistan J Biol Sci 15 (15): 720-728.

Ikhwanuddin M, Shabdin ML, Abol-Munafi AB. 2009. Size at maturity of blue swimming crab (Portunus pelagicus) found in Sarawak Coastal Waters. Journal of Sustainability Science and Management 4 (1): 5665

Ingles JA, Bkaum E. 1989 Reproduction and larval ecology of the blue swimming crab, Portunus pelagicus, in Ragay Gulf, Philippines. Internationale Revue der gesamten Hydrobiologie und Hydrographie 74 (5): 471-490.

Johnson DD, Gray CA, William G, Macbeth WG. 2010. Reproductive biology of Portunus pelagicus in a South-East Australian Estuary. J Crustacean Biol 30 (2): 200-205.

King, M. 1995. Fisheries Biology, Assessment, and Management, ISBN: 978-1-4051-5831-2. Blackwell Publishing, New York.

Madduppa H, Zairion, Nuraini S, Nugroho KC, Nugraha BA. 2016. Setting up a traceability tools for the Indonesian Blue Swimming Crab Fishery: a case study in Southeast Sulawesi. In: Fisheries and Aquaculture in the Modern World. Intech, Rijeca, Croatia. DOI: $10.5772 / 64252$

MMAF [Ministry of Marine Affairs and Fisheries]. 2012. Capture fisheries statistics of Indonesia, 2011. Vol. 12, No. 1. Jakarta. 
Nomura M. 1974. Gillnet Fishery. Japanese Fishing Gear and Method Text Book for Marine Fisheries Research Course. Overseas Technical Cooperation Agency. Government of Japan, Tokyo.

Oh CW, Hartnoll RG. 1999 Size at sexual maturity, reproductive output, and seasonal reproduction of Philocheras trispinosus (Decapoda) in Port Erin Bay, Isle of Man. J Crustacean Biol 19 (2): 252-259.

Pauly D. 1980. On the interrelationships between natural mortality, growth parameters and mean environmental temperature in 175 fish stocks. J. Cons. CIEM 39 (3): 175-92.

Pinheiro MAA, Fransozo A. 2002 Reproduction of the speckled swimming crab Arenaeus cribrarius (Brachyura: Portunidae) on the Brazilian Coast near 233' S. J Crustacean Biol 22 (2): 416-428.

Prince J, Hordyk A, Valencia SR, Loneragan N, Sainsbury K. 2015. Revisiting the concept of Beverton-Holt life history invariants with the aim of informing data poor fisheries assessment. ICES J Mar Sci 72 (1): 194-203

Rasheed S, Mustaquim J. 2010 Size at sexual maturity, breeding season and fecundity of three-spot swimming crab Portunus sanguinolentus (Herbst, 1783) (Decapoda, Brachyura, Portunidae) occurring in the coastal waters of Karachi, Pakistan. Fish Res 103: 56-62.

Ricker WE. 1973. Linear regressions in fishery research. J Fish Res Board Can 30: 409-434.

Sahoo D, Panda S, Guru BC. 2011. Studies on reproductive biology and ecology of blue swimming crab, Portunus pelagicus from Chilika Lagoon, Orissa, India. J Mar Biol Assoc UK 91 (1): 257-264.
Stearns SC. 1989. Essay Review: Trade-offs in life-history evolution. Funct Ecol 3 (3): 259-268

Sukumaran KK, Neelakantan B. 1996. Relative growth and sexual maturity in the marine crabs, Portunus (Portunus) sanguinolentus (Herbst) and Portunus (Portunus) pelagicus (Linnaeus) along the southwest coast of India. Indian J Fish 43 (3): 215-223.

Sukumaran KK, Neelakantan B. 1997. Length-Weight Relationship in Two Marine Portunid Crabs Portunus sanguinolentus (Herbst) and Portunus pelagicus (Linnaeus) from the Karnataka Coast. Indian J Mar Sci 26: 39-42.

Sumiono B, Widodo AA. 2006. Some fishing gear used in demersal and shrimps fisheries in Malacca Strait. Paper presented at "National Seminar on Indonesian Fishery 2006. December 12-13, 2006. Fishery College, Jakarta. [Indonesian]

Sumiono B. 1997. Fishing activities in relation to commercial and smallscale fisheries in Indonesia. Proceeding of the Regional Workshop on Responsible Fishing. Bangkok, Thailand. SEAFDEC, Samutprakarn, Thailand.

Sumpton WD, Potter MA, Smith GS. 1994. Reproduction and growth of the commercial sand crab, Portunus pelagicus (Linn.) in Moreton Bay, Queensland. Asian Fish Sci 7: 103-113.

Zairion, Wardiatno Y, Fahrudin A. 2015. Sexual maturity, reproductive pattern and spawning female population of the Blue Swimming Crab, Portunus pelagicus (Brachyura: Portunidae) in East Lampung Coastal Waters, Indonesia. Indian J Sci Technol 8 (6): 596-607. 